\title{
MOSCOW AS AN INTERNATIONAL FINANCIAL CENTRE
}

\author{
ELIZAVETA OGLOBLINA
}

Financial University under the Government of the Russian Federation, Moscow, Russia

\section{ABSTRACT}

The creation, development, and function of the international financial centres (IFC) is the subject of the international finance investigation. The article deals with the perspectives of the Russian IFC. The paper embraces a wide range of challenges that are faced nowadays in the Russian Federation as a whole, and particularly Moscow. The article presents the comparative analyses of different rating and indices, which reflect the current situation in the business and financial situation of the country.

\section{JEL CLASSIFICATION \& KEYWORDS}

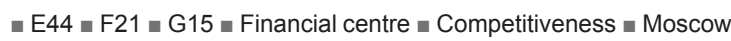
INTRODUCTION

By definition, financial centres are cities and countries; which mobilize and redistribute a considerable volume of financial resources. Such centres usually combine the complexity of banking and financial institutions, carrying out foreign exchange, financial and credit operations, transactions with commodities, and different securities.

The situation of the Russian financial centre is complex; it has the topical significance and requires a detailed study. The questions which are of great practical importance deal with the following areas: firstly, the best suitable type of the IFC for Russia; secondly, the evaluation of current socio-economic development; and thirdly, the measures and steps for the IFC creation.

It is important to mention, in this particular situation, that it is possible to distinguish two aspects: legal and factual. The legal aspects are found its reflection in "The Conception of the IFC creation in the Russian Federation" (Conception). According to this document; Moscow must become "one of the leading centres in the Eurasian Area along with Shanghai and Dubai within 5 years prior to 2013". Certainly the creation of an IFC in the capital of Russia is logical. It is assumed that Moscow should become a centre of banking and financial services in the region.

The factual aspect consists of the objective analysis and evaluation of the economic, infrastructural, and political situation in Russia as a whole, also Moscow in particular. To examine all these points in detail, we must turn first of all to the IFCs' classifications. It is necessary to point out that there are different typologization criteria of IFCs.

\section{IFCs' classification}

Thus, in accordance with the historical origin, IFCs can be divided into old and new financial centres. The creation and development of old IFCs (e.g. London, New York, Frankfurt) can be explained by geopolitical reasons. The development of new IFCs (e.g. Singapore, Hong Kong, and Dubai) began in the $20^{\text {th }}$ century and was the result of a special economic environment.

The presented classification enables us to draw a conclusion that on one hand, Russia has unique geopolitical features that influence the IFC creation positively. On the other hand, the development of an IFC requires the immediate creation of favorable economic conditions and special regulation mechanisms to achieve completion within 5 years prior to the year 2013 .
Let us now turn to the IFCs' classification that is proposed in the Conception, which is bound up with a spectrum of available financial services. According to the classification, IFCs fall into the following types of services:

- Global: wide range of financial services (London, New York);

- regional: regional specialization (Hong Kong, Singapore, Dubai);

- local: financial services for a national market (Tokyo, Frankfurt, Paris);

- offshore: special financial services (Zurich, Geneva, Jersey, Cayman Islands).

The classification evidently demonstrates the existing possibilities in choosing an IFC profile. One can safely say that the creation of an IFC in Russia is hardly possible in the middle-term perspective. The explanation is quite simple: the IFC can be created only on the basis of gradual economic development; which is impossible without modern industrial technologies. This condition is also true for global financial centres, as well as for regional financial centres.

In 1999 the Globalization and World Cities Study Group (GaWC) from Loughborough University (UK) suggested to range cities in levels of advanced producer services. Global service centres are graded for accountancy, advertising, banking/finance, and law. Therefore, three levels of world cities were distinguished. It should be noted that Moscow joined the list of world cities in 1998, which means that the city is deeply integrated into the global economy (Table 1).

\begin{tabular}{|l|l|}
\hline \multicolumn{2}{|c|}{ Table 1: Inventory of world cities (1998) } \\
\hline 12 & London, New York, Paris, Tokyo \\
\hline 10 & $\begin{array}{l}\text { Chicago, Frankfurt, Hong Kong, Los Angeles, Milan, } \\
\text { Singapore }\end{array}$ \\
\hline \multicolumn{1}{|c|}{ B. Beta World Cities (major world cities) } \\
\hline 9 & San Francisco, Sydney, Toronto, Zurich \\
\hline 8 & Brussels, Madrid, Mexico City, Sao Paulo \\
\hline 7 & Moscow, Seoul \\
\hline 6 & $\begin{array}{l}\text { Amsterdam, Bamma World Cities (minor world cities) Caracas, Dallas, Düsseldorf, Geneva, } \\
\text { Houston, Jakarta, Johannesburg, Melbourne, Osaka, Prague, } \\
\text { Santiago, Taipei, Washington }\end{array}$ \\
\hline 5 & Bangkok, Beijing, Montreal, Rome, Stockholm, Warsaw \\
\hline 4 & $\begin{array}{l}\text { Atlanta, Barcelona, Berlin, Budapest, Buenos Aires, } \\
\text { Copenhagen, Hamburg, Istanbul, Kuala Lumpur, Manila, Miami, } \\
\text { Minneapolis, Munich, Shanghai }\end{array}$ \\
\hline $\begin{array}{l}\text { Source: Calculated by the authors from commercial banks' annual } \\
\text { reports }\end{array}$ \\
\hline
\end{tabular}

According to the latest research of the Study Group, published on September, 14 2011; Moscow continues to remain among the leading cities of the world, such as Milan, Beijing, Toronto, Mexico, Amsterdam etc.

Moscow's high ranking in this rating causes lots of discussions among the experts. It should be kept in mind that a world city is the economic centre of the post-industrial era and it should offer the wide range of financial and social services. It is very doubtful though, that Moscow corresponds to these criteria. 


\begin{tabular}{|c|c|c|c|c|c|c|c|c|c|c|}
\hline & \begin{tabular}{|l|} 
GFCl \\
(Sept. \\
2011) \\
\end{tabular} & \begin{tabular}{|l|} 
GFCl9 \\
(March \\
2011) \\
\end{tabular} & $\begin{array}{l}\text { GFCl8 } \\
\text { (Sept. } \\
2010) \\
\end{array}$ & $\begin{array}{l}\text { GFCl7 } \\
\text { (March } \\
2010) \\
\end{array}$ & \begin{tabular}{|l} 
GFCl6 \\
(Sept. \\
2009) \\
\end{tabular} & $\begin{array}{l}\text { GFCl5 } \\
\text { (March } \\
2009) \\
\end{array}$ & $\begin{array}{l}\text { GFCl4 } \\
\text { (Sept. } \\
2008) \\
\end{array}$ & $\begin{array}{l}\text { GFCl3 } \\
\text { (March } \\
\text { 2008) } \\
\end{array}$ & \begin{tabular}{|l} 
GFCl2 \\
(Sept. \\
2007) \\
\end{tabular} & \begin{tabular}{|l} 
GFCl \\
(March \\
2007) \\
\end{tabular} \\
\hline London & 1 & 1 & 1 & 1 & 1 & 1 & 1 & 1 & 1 & 1 \\
\hline New York & 2 & 2 & 2 & 1 & 2 & 2 & 2 & 2 & 2 & 2 \\
\hline Hong Kong & 3 & 3 & 3 & 3 & 3 & 4 & 4 & 3 & 3 & 3 \\
\hline Singapore & 4 & 4 & 4 & 4 & 4 & 3 & 3 & 4 & 4 & 4 \\
\hline Shanghai & 5 & 5 & 6 & 11 & 10 & 35 & 34 & 31 & 30 & 24 \\
\hline Tokyo & 6 & 5 & 5 & 5 & 7 & 15 & 7 & 9 & 10 & 9 \\
\hline Zurich & 8 & 8 & 8 & 7 & 6 & 5 & 5 & 5 & 5 & 5 \\
\hline Frankfurt & 16 & 14 & 11 & 13 & 12 & 8 & 9 & 6 & 6 & 6 \\
\hline Paris & 24 & 20 & 18 & 20 & 19 & 19 & 20 & 14 & 11 & 11 \\
\hline Dubai & 36 & 28 & 28 & 24 & 21 & 23 & 23 & 24 & 22 & 25 \\
\hline Sao Paulo & 49 & 44 & 44 & 40 & 41 & 54 & 52 & 53 & 49 & 0 \\
\hline Warsaw & 56 & 59 & 67 & 67 & 69 & 59 & 56 & 55 & 48 & 40 \\
\hline Moscow & 61 & 68 & 68 & 68 & 67 & 60 & 57 & 56 & -51 & 45 \\
\hline Saint-Petersburg & 71 & 69 & 71 & 70 & 70 & - & - & - & - & - \\
\hline
\end{tabular}

\section{Competitiveness ratings of IFCs}

Since 2007, the analytical centre of consulting company Z/Yen Group Limited, based in London, publishes biannually the Global Financial Centres Index (GFCl) in terms of competitiveness. The instrumental factors used in the $\mathrm{GFCl}$ model are grouped into five areas of competitiveness: People, Business Environment, Market Access, Infrastructure, and General Competitiveness. The Table 2 contains the data on the GFCl from 2007 to 2011.

The complete analysis of the presented GFCI ranks reveals the indisputable leadership of London, New York, Hong Kong, and Singapore. Zurich, Frankfurt, and Paris rank stable high positions. What is especially noteworthy is the Shanghai rating, which extremely grew up during the last five years.

As far as Moscow is concerned, we can conclude, that in the last six months of 2011 the city improved its position by moving into $61^{\text {st }}$ place, up seven points in the ratings (among 75 financial centres). The higher Moscow positions in the ratings in 2007-2009 can be explained by narrow statistical data.

Thus, Moscow is still the "global contender" to the IFC. This, of course, is not enough. Skeptics reckon, that the high-level declaration about the IFC creation has allowed Moscow to enter the ratings.

Nevertheless, it should be noted that most of experts and business representatives think that Russia needs an IFC; which will attract foreign direct investments (FDI) in the country. Let us draw our attention to the figures. In 2006 the net capital inflow to Russia was 41.4 bln USD, in 2007 - 81.7 bln USD. However, the situation has changed dramatically in the recent years, especially in 2011. In 2008 the net capital outflow from Russia was 130.2 bln USD, in 2009 - 56.1 bln USD, in 2010 - 33.6 bln USD. In the first three quarters of 2011 the net capital outflow from Russia was 50 bln USD. So, the investment climate in Russia can be characterized as extremely negative.

To a certain extent this situation can be explained by the fact that Moscow ranks very low positions in different ratings, which were prepared by the international financial institutions. The potential investors are aware of the unexpected problems in the market.

In the past few years Russia ranks 63 (among 139) in the ratings of the World Economic Forum, which is called the
Global Competitiveness Index (GCI). The Table 3 contains the information on it.

The GCl evaluates the perspectives of economic growth for different countries in the middle and long term period.

Such countries, as the UAE, Poland, and Brazil improved their positions in the ratings in 2007-2011; moving up 12, 12 , and 14 points respectively.

Russia has not improved its positions in the ratings. In comparison to 2007 the country has lost five points. It seems essential to emphasize that in 2010-2011 Russia ranks $125^{\text {th }}$ in the pillar of the level of financial market development, $128^{\text {th }}$ in the pillar of the property rights, $132^{\text {nd }}$ in the pillar of the protection of minority of shareholders interests.

Another solid international indicator of economic development in the global competitive environment is the World Competitiveness Scoreboard, prepared by the IMD, Switzerland. The IMD World Competitiveness Scoreboard measures 59 countries on the basis of four criteria groups: economic performance, government efficiency, business efficiency, and infrastructure. Compared to 2007 Russia has dropped six places in the ratings to $49^{\text {th }}$ place (Table 4 ).

One can safely say that the loss in rating positions does not always reflect problems in an economy. Nevertheless, the contents in Table 4 demonstrate that Russia always loses in comparison to other countries.

The experts of the China Finance Corporation Holding Company, which is the daughter company of the Xinhua News Agency and the CME Group Index Services LLC; which is the part of the Dow Jones Indexes Company, calculate International Financial Centers Development Index (IFCD). The indicator system values IFCs from five aspects, i.e. financial market, growth and development, industrial support, service, and general environment. It uses questionnaires to collect survey subjects' opinions from different groups of people.

In 2011 the research group came to a comprehensive ranking of 45 IFCs (Table 5).

Thus, in 2011 the most competitive IFCs were New York, London, and Tokyo. Moscow ranked only $35^{\text {th }}$.

There is not the least doubt that the investors, deciding about capital movements, take into consideration these results and indicators as well. 
Table 3: Global competitiveness index

\begin{tabular}{|c|c|c|c|c|c|}
\hline & \multicolumn{2}{|c|}{ GCI 2010-2011 } & \multirow{2}{*}{$\begin{array}{l}\mathrm{GCl} \\
2009- \\
2010\end{array}$} & \multirow{2}{*}{$\begin{array}{l}\mathrm{GCl} \\
2008- \\
2009\end{array}$} & \multirow{2}{*}{$\begin{array}{l}\mathrm{GCl} \\
2007- \\
2008\end{array}$} \\
\hline & Rank & Score & & & \\
\hline Switzerland & 1 & 5,63 & 1 & 2 & 2 \\
\hline Singapore & 3 & 5,48 & 3 & 5 & 7 \\
\hline USA & 4 & 5,43 & 2 & 1 & 1 \\
\hline Germany & 5 & 5,39 & 7 & 7 & 5 \\
\hline Japan & 6 & 5,37 & 8 & 9 & 8 \\
\hline Hong Kong & 11 & 5,3 & 11 & 11 & 12 \\
\hline UK & 12 & 5,25 & 13 & 12 & 9 \\
\hline Taiwan, China & 13 & 5,21 & 12 & 17 & 14 \\
\hline France & 15 & 5,13 & 16 & 16 & 18 \\
\hline UAE & 25 & 4,89 & 23 & 31 & 37 \\
\hline Poland & 39 & 4,51 & 46 & 53 & 51 \\
\hline Brasil & 58 & 4,28 & 56 & 64 & 72 \\
\hline Russia & 63 & 4,24 & 63 & 51 & 58 \\
\hline Kazakhstan & 72 & 4,12 & 67 & 66 & 61 \\
\hline
\end{tabular}

Source: The Global Competitiveness Report (2007-2008, 20082009, 2009-2010, 2010-2011)

\begin{tabular}{|c|c|c|c|c|c|}
\hline & 2011 & 2010 & 2009 & 2008 & 2007 \\
\hline Hong Kong & 1 & 2 & 2 & 3 & 3 \\
\hline USA & 1 & 3 & 1 & 1 & 1 \\
\hline Singapore & 3 & 1 & 3 & 2 & 2 \\
\hline Switzerland & 5 & 4 & 4 & 4 & 6 \\
\hline Taiwan & 6 & 8 & 23 & 13 & 18 \\
\hline Germany & 10 & 16 & 13 & 16 & 16 \\
\hline China & 19 & 18 & 20 & 17 & 15 \\
\hline UK & 20 & 22 & 21 & 21 & 20 \\
\hline Japan & 26 & 27 & 17 & 22 & 24 \\
\hline UAE & 28 & - & - & - & - \\
\hline France & 29 & 24 & 28 & 25 & 28 \\
\hline Poland & 34 & 32 & 44 & 44 & 52 \\
\hline Kazakhstan & 36 & 33 & 36 & - & - \\
\hline Brasil & 44 & 38 & 40 & 43 & 49 \\
\hline Russia & 49 & 51 & 49 & 47 & 43 \\
\hline
\end{tabular}

Source: IMD World Competitiveness Yearbook $(2007,2008,2009$, 2010, 2011)

\begin{tabular}{|l|l|l|}
\hline Table 5: International financial centers development index, 2011 \\
\hline & Rank & Score \\
\hline New-York & 1 & 87,69 \\
\hline London & 2 & 85,96 \\
\hline Tokyo & 3 & 85,81 \\
\hline Hong Kong & 4 & 82,18 \\
\hline Singapore & 5 & 74,53 \\
\hline Shanghai & 6 & 71,42 \\
\hline Paris & 7 & 71,37 \\
\hline Frankfurt & 8 & 64,4 \\
\hline Zurich & 12 & 54 \\
\hline Dubai & 16 & 51 \\
\hline Moscow & $\mathbf{3 5}$ & $\mathbf{3 5 , 4}$ \\
\hline Sao Paulo & 41 & 29,71 \\
\hline $\begin{array}{l}\text { Source: Xinhua-Dow Jones } \\
\text { Development Index, 2011, p. 5 }\end{array}$ & \\
\hline
\end{tabular}

Let us now turn to the World Bank Doing Business Rating, which investigates the regulations that enhance business activity and those that constrain it. According to the ratings

\begin{tabular}{|l|l|l|l|l|}
\hline Table 6: Doing business ratings \\
\hline & \multicolumn{5}{|c|}{ Rankings } \\
\hline & 2012 & 2011 & 2010 & 2009 \\
\hline Singapore & 1 & 1 & 1 & 1 \\
\hline Hong Kong (China) & 2 & 2 & 3 & 3 \\
\hline USA & 4 & 4 & 4 & 4 \\
\hline UK & 7 & 6 & 5 & 6 \\
\hline Germany & 19 & 19 & 25 & 27 \\
\hline Japan & 20 & 20 & 15 & 13 \\
\hline Taiwan (China) & 25 & 24 & 41 & 61 \\
\hline Switzerland & 26 & 22 & 21 & 19 \\
\hline France & 29 & 26 & 31 & 31 \\
\hline UAE & 33 & 35 & 33 & 47 \\
\hline Kazakhstan & 47 & 58 & 63 & 64 \\
\hline Poland & 62 & 59 & 72 & 72 \\
\hline Russia & 120 & 124 & 120 & 118 \\
\hline Brasil & 126 & 120 & 129 & 127 \\
\hline Source: Doing Business (2010, 2012$)$ & & \\
\hline
\end{tabular}

data, Russia ranks only $120^{\text {th }}$ place among 183 countries. Here are the rankings for 2009-2012 (Table 6).

Doing Business measures and tracks changes in regulations affecting 10 areas in the life cycle of a business: starting a business, dealing with construction permits, getting electricity, registering property, getting credit, protecting investors, paying taxes, trading across borders, enforcing contracts, and resolving insolvency. The Table 7 illustrates the aspects mentioned above.

What clearly demonstrates problems within Russia's low rankings is business environment. The business environment does not appeal to foreign investors; which is a very negative issue.

Additionally, it may be interesting and beneficial to analyze the Corruption Perceptions Index, for it summarizes the opinions of independent experts and ranking countries according to the perception of corruption. It scores countries on a scale of 0 to 10 , where 0 is perceived to be highly corrupt and 10 indicates low levels of corruption (Table 8).

The high scores of the developed countries reflect the relative wellbeing in the public sectors that are backed by stable political situations, efficient conflict resolving mechanisms, information disclosure policies, and public control.

Traditionally Russia ranks very low in the ratings, i.e. in 2010 it was in $154^{\text {th }}$ place among 178 countries. According to the index methodology, bribery is a very serious problem in the countries that scored less than 3 . Unfortunately, this problem has not been solved in Russia.

\section{IFCs' infrastructure}

Another actual challenge for Moscow as an IFC is the infrastructure's improvement: i.e. transport, communication networks, qualified human resources, etc.

According to the Economist Intelligence Unit (EIU), in 2011 Moscow ranked $70^{\text {th }}$ place among the 140 most comfortable cities in the world. The rating is assigned across 30 indicators, grouped into five broad categories: stability, healthcare, culture and environment, education, and infrastructure (Economist, 2011).

Moscow also ranks low positions in the Global Power City Index, prepared by the Institute for Urban Strategies (The Mori Memorial Foundation) since 2008. The Index assesses 


\begin{tabular}{|c|c|c|c|c|c|c|c|c|c|c|}
\hline & \begin{tabular}{|l|}
$\begin{array}{l}\text { Starting a } \\
\text { business }\end{array}$ \\
\end{tabular} & \begin{tabular}{|l|} 
Dealing \\
with \\
construct \\
ion permits \\
\end{tabular} & $\begin{array}{l}\text { Getting } \\
\text { electricity }\end{array}$ & \begin{tabular}{|l|} 
Registering \\
property
\end{tabular} & $\begin{array}{l}\text { Getting } \\
\text { credit }\end{array}$ & $\begin{array}{l}\text { Protecting } \\
\text { investors }\end{array}$ & \begin{tabular}{|l|} 
Paying \\
taxes
\end{tabular} & $\begin{array}{l}\text { Trading } \\
\text { across } \\
\text { borders }\end{array}$ & $\begin{array}{l}\text { Enforcing } \\
\text { contracts }\end{array}$ & $\begin{array}{l}\text { Resolving } \\
\text { insolve } \\
\text { ncy }\end{array}$ \\
\hline Singapore & 4 & 3 & 5 & 14 & 8 & 2 & 4 & 1 & 12 & 2 \\
\hline Hong Kong (China) & 5 & 1 & 4 & 57 & 4 & 3 & 3 & 2 & 5 & 16 \\
\hline USA & 13 & 17 & 17 & 16 & 4 & 5 & 72 & 20 & 7 & 15 \\
\hline UK & 19 & 22 & 60 & 68 & 1 & 10 & 24 & 13 & 21 & 6 \\
\hline Germany & 98 & 15 & 2 & 77 & 24 & 97 & 89 & 12 & 8 & 36 \\
\hline Japan & 107 & 63 & 26 & 58 & 24 & 17 & 120 & 16 & 34 & 1 \\
\hline Taiwan (China) & 16 & 87 & 3 & 33 & 67 & 79 & 71 & 23 & 88 & 14 \\
\hline Switzerland & 85 & 46 & 6 & 14 & 24 & 166 & 12 & 41 & 23 & 43 \\
\hline France & 25 & 30 & 62 & 149 & 48 & 79 & 58 & 24 & 6 & 46 \\
\hline UAE & 42 & 12 & 10 & 6 & 78 & 122 & 7 & 5 & 134 & 151 \\
\hline Russia & 111 & 178 & 183 & 45 & 98 & 111 & 105 & 160 & 13 & 60 \\
\hline
\end{tabular}

\begin{tabular}{|l|l|l|l|l|l|l|l|l|l|l|}
\hline Table 8: Corruption perceptions index \\
\hline & 2010 & 2009 & 2008 & 2007 & 2006 & 2005 & 2004 & 2003 & 2002 & 2001 \\
\hline Singapore & 9,3 & 9,2 & 9,2 & 9,3 & 9,4 & 9,4 & 9,3 & 9,4 & 9,3 & 9,2 \\
\hline Switzerland & 8,7 & 9 & 9 & 9 & 9,1 & 9,1 & 9,1 & 8,8 & 8,5 & 8,4 \\
\hline Hong Kong & 8,4 & 8,2 & 8,1 & 8,3 & 8,3 & 8,3 & 8 & 8 & 8,2 & 7,9 \\
\hline Germany & 7,9 & 8 & 7,9 & 7,8 & 8 & 8,2 & 8,2 & 7,7 & 7,3 & 7,4 \\
\hline Japan & 7,8 & 7,7 & 7,3 & 7,5 & 7,6 & 7,3 & 6,9 & 7 & 7,1 & 7,1 \\
\hline UK & 7,6 & 7,7 & 7,7 & 8,4 & 8,6 & 8,6 & 8,6 & 8,7 & 8,7 & 8,3 \\
\hline USA & 7,1 & 7,5 & 7,3 & 7,2 & 7,3 & 7,6 & 7,5 & 7,5 & 7,7 & 7,6 \\
\hline France & 6,8 & 6,9 & 6,9 & 7,3 & 7,4 & 7,5 & 7,1 & 6,9 & 6,3 & 6,7 \\
\hline UAE & 6,3 & 6,5 & 5,9 & 5,7 & 6,2 & 6,2 & 6,1 & 5,2 & - \\
\hline Poland & 5,3 & 5 & 4,6 & 4,2 & 3,7 & 3,4 & 3,5 & 3,6 & 4 & - \\
\hline Brasil & 3,7 & 3,7 & 3,5 & 3,5 & 3,3 & 3,7 & 3,9 & 3,9 & 4 \\
\hline China & 3,5 & 3,6 & 3,6 & 3,5 & 3,3 & 3,2 & 3,4 & 3,4 & 3,5 \\
\hline Kazakhstan & 2,9 & 2,7 & 2,2 & 2,1 & 2,6 & 2,6 & 2,2 & 2,4 & 2,3 \\
\hline Russia & $\mathbf{2 , 1}$ & $\mathbf{2 , 2}$ & $\mathbf{2 , 1}$ & $\mathbf{2 , 3}$ & $\mathbf{2 , 5}$ & $\mathbf{2 , 4}$ & $\mathbf{2 , 8}$ & $\mathbf{2 , 7}$ & $\mathbf{2 , 7}$ \\
\hline Source: Corruption & Perceptions Index (2001,2002, $2003,2004,2005,2006,2007,2008,2009,2010)$ & $\mathbf{2 , 3}$ \\
\hline
\end{tabular}

\begin{tabular}{|l|l|l|l|l|}
\hline Table 9: Global power city index \\
\hline & 2011 & 2010 & 2009 & 2008 \\
\hline New York & 1 & 1 & 1 & 1 \\
\hline London & 2 & 2 & 2 & 2 \\
\hline Paris & 3 & 3 & 3 & 3 \\
\hline Tokyo & 4 & 4 & 4 & 4 \\
\hline Singapore & 5 & 5 & 5 & 11 \\
\hline Hong Kong & 8 & 9 & 10 & 17 \\
\hline Frankfurt & 10 & 13 & 16 & 16 \\
\hline Zurich & 14 & 12 & 9 & 15 \\
\hline Shanghai & 23 & 26 & 21 & 25 \\
\hline Sao Paulo & 32 & 33 & 33 & - \\
\hline Moscow & $\mathbf{3 3}$ & $\mathbf{3 2}$ & $\mathbf{3 2}$ & $\mathbf{2 3}$ \\
\hline Source: Global Power City Index (2009, p. 13, 2011, p. 8) \\
\hline
\end{tabular}

35 cities around the world. New York, London, Paris, Tokyo, and Singapore are traditionally in the top of the list (Table 9).

It should be added in this connection that the evaluation of the world's major cities is based on six main functions representing city strength: economy, R\&D, cultural interaction, livability, environment, and accessibility. Four global actors who are leading the urban activities in their city (managers, researches, artists and visitors) and one local actor (residents) examine cities from multiple angles.

\begin{tabular}{|l|l|l|l|l|}
\hline Table 10: Mercer's cost of living rating \\
\hline & $\begin{array}{l}\text { March } \\
2011\end{array}$ & $\begin{array}{l}\text { March } \\
2010\end{array}$ & $\begin{array}{l}\text { March } \\
2009\end{array}$ & $\begin{array}{l}\text { March } \\
2008\end{array}$ \\
\hline Moscow & 4 & 4 & 3 & 1 \\
\hline Zurich & 7 & 6 & 6 & 9 \\
\hline Singapore & 8 & 11 & 10 & 13 \\
\hline Hong Kong & 9 & 8 & 5 & 6 \\
\hline Sao Paulo & 10 & 21 & 72 & 25 \\
\hline London & 18 & 17 & 16 & 3 \\
\hline Shanghai & 21 & 25 & 12 & 24 \\
\hline Paris & 27 & 17 & 13 & 12 \\
\hline Saint-Petersburg & 29 & 30 & 46 & 18 \\
\hline New York & 32 & 27 & 8 & 22 \\
\hline Dubai & - & - & 20 & 52 \\
\hline Alma-Ata & - & - & 44 & 44 \\
\hline Frankfurt & - & - & 48 & 40 \\
\hline Source: Word Wide & & - & 4 & \\
\hline
\end{tabular}

Source: World Wide Cost of Living Survey (March 2008, March 2009, March 2010, March 2011)

It is worth, however, adding the rating of the Mercer Human Resource Consulting, which is called Mercer's Cost of Living Survey. Mercer measures the comparative cost of over 200 items in each location, including housing, transport, food, etc. New York is used as the base city for the Index and scores 100 points. 
Moscow ranks leading positions in this rating (Table 10).

Furthermore, the global financial centres (e.g. London and New York) are not in the top of the rating.

\section{Conclusion}

After carrying out a comparative description and analysis, it became possible to arrive at the following conclusions. The imperative of the IFC development in Russia is a balanced macroeconomic policy and political stability. Moscow should become a comfortable city for working and living. Surveys demonstrate the necessity of the overall city's infrastructure modernization. Without proper conditions, the creation of an IFC in Moscow is almost impossible.

\section{REFERENCES}

1. Corruption Perceptions Index. Transparency International. 2001. <http://transparency.org/policy_research/surveys_indices/cpi/2001>

2. Corruption Perceptions Index. Transparency International. 2002. <http://transparency.org/policy_research/surveys_indices/cpi/2002>

3. Corruption Perceptions Index. Transparency International. 2003. <http://transparency.org/policy_research/surveys_indices/cpi/2003>

4. Corruption Perceptions Index. Transparency International. 2004. <http://transparency.org/policy_research/surveys_indices/cpi/2004>

5. Corruption Perceptions Index. Transparency International. 2005. <http://transparency.org/policy_research/surveys_indices/cpi/2005>

6. Corruption Perceptions Index. Transparency International. 2006. <http://transparency.org/policy_research/surveys_indices/cpi/2006>

7. Corruption Perceptions Index. Transparency International. 2007. <http://transparency.org/policy_research/surveys_indices/cpi/2007>

8. Corruption Perceptions Index. Transparency International. 2008. <http://transparency.org/policy_research/surveys_indices/cpi/2008>

9. Corruption Perceptions Index. Transparency International. 2009. <http://transparency.org/policy_research/surveys_indices/cpi/2009>

10. Corruption Perceptions Index. Transparency International. 2010. <http://transparency.org/policy_research/surveys_indices/cpi/2010> 11. Doing Business 2010. Washington, USA: IBRD/World Bank. 2009. Web. 24.04.2012.

12. Doing Business 2012. Washington, USA: IBRD/World Bank. 2011. Web. 24.04.2012.

13. The Global Competitiveness Report 2007-2008. Geneva, Switzerland: The World Economic Forum. 2007. Web. 24.04.2012.

14. The Global Competitiveness Report 2008-2009. Geneva, Switzerland: The World Economic Forum. 2008. Web. 24.04.2012.

15. The Global Competitiveness Report 2009-2010. Geneva, Switzerland: The World Economic Forum. 2009. Web. 24.04.2012.

16. The Global Competitiveness Report 2010-2011. Geneva, Switzerland: The World Economic Forum. 2010. Web. 24.04.2012.

17. The Global Financial Centres Index. City of London, UK: Z/Yen Group. March 2007. Web. 24.04.2012.

18. The Global Financial Centres Index. City of London, UK: Z/Yen Group. Sept. 2007. Web. 24.04.2012.

19. The Global Financial Centres Index. City of London, UK: Z/Yen Group. March 2008. Web. 24.04.2012.

20. The Global Financial Centres Index. City of London, UK: Z/Yen Group. Sept. 2008. Web. 24.04.2012.

21. The Global Financial Centres Index. City of London, UK: Z/Yen Group. March 2009. Web. 24.04.2012.

22. The Global Financial Centres Index. City of London, UK: Z/Yen Group. Sept. 2009. Web. 24.04.2012.

23. The Global Financial Centres Index. City of London, UK: Z/Yen Group. March 2010. Web. 24.04.2012.

24. The Global Financial Centres Index. City of London, UK: Z/Yen Group. Sept. 2010. Web. 24.04.2012.

25. The Global Financial Centres Index. City of London, UK: Z/Yen Group. March 2011. Web. 24.04.2012.
26. The Global Financial Centres Index. City of London, UK: Z/Yen Group. Sept. 2011. Web. 24.04.2012.

27. Global Power City Index 2011. Tokyo, Japan: Institute for Urban Strategies. The Mori Memorial Foundation. Oct. 2011. Web. 24.04.2012.

28. Global Power City Index 2009. Tokyo, Japan: Institute for Urban Strategies. The Mori Memorial Foundation. Oct. 2009. Web. 24.04.2012.

29. "IMD World Competitiveness Yearbook." World Competitiveness Scoreboard. 2007. 2008. 2009. 2010. 2011. IMD <http://www.imd.org /research/publications/wcy/index.cfm>

30. "Inventory of World Cities." Globalization and World Cities (GaWC) Research Network. 1998. Loughborough University <http://www.lboro.ac.uk/gawc/citylist.html>

31. "A Summary of the Liveability Ranking and Overview." Economist Intelligence Unit Limited. 2011. <https://www.eiu.com/public/ topical_report.aspx?campaignid=Liveability2011>

32. "World Wide Cost of Living Survey." Mercer <http://www.mercer. com/costoflivingpr\#City_rankings>

33. Xinhua-Dow Jones International Financial Centers Development Index. Beijing, China: CFC Holding Company, Ltd., Index Center. CME Group Index Services LLC (Dow Jones Indexes). July 2011. Web. 24.04.2012. 